\title{
Beyond the Rule of Thumb: The Materiality of Marital Violence in England c. 1700-1857
}

\section{Joanne Begiato}

\section{Introduction}

Marital violence is profoundly shaped by the material world. Eighteenth- and nineteenth-century court cases catalogue abusive husbands' use of dwellings and domestic objects to imprison, beat, threaten, and intimidate their wives. Print culture from this era similarly viewed wife beating in material terms. The author of 'Overcrowded Dwellings' (1857) for example, linked cheap, poor quality houses to domestic violence. Cramped and dirty, the 'male portions of the households dislike the appearance and the noisomeness of their room, and they stop at the parlour of the public house.' Their wives followed suit or became slatterns; the result 'a perpetual motion of a moral and immoral character,' expressed in marital violence.1 This article contends that investigating the materiality of marital abuse through its articulation in and around particular places, spaces, and objects focuses our attention upon its intensely visceral dimensions, exposing the human suffering at its centre. It also adopts the conceptual premise that spaces and objects are 'actants,' a term coined by the theorist Bruno Latour 'to describe anything that has agency (and for Latour, everything does).'2 Thus, the article explores the patriarchal tensions embedded in the physical structure of the household and its control, arguing that space and objects shaped marital violence both as an act and an idea. Moreover, it proposes that the material culture of marital abuse performed 'emotional work' in the sense that it acted upon people's perceptions, influencing social and cultural constructions of wife beating across the period.

1 'Overcrowded Dwellings', Tait's Edinburgh Magazine, Sep 1857, p 561. 


\section{Marital Violence and Material History}

Research into the history of marital violence has taken several shifts in approaches and findings. Pioneering work in the 1970 s and ' 80 s driven by feminist historians, and historians of women and crime, established causes and measured the incidence of marital violence in the past, concluding that its potential influenced everyone's married life.3 This proved controversial, due to the 'dark figure' of unreported and undiscovered incidents, and to wife beating's ambivalent status, since husbands could legitimately 'correct' disobedient wives using moderate physical force in this period, although wives had legal recourse against acts defined as cruel.4 Instead, social historians used court cases of marital violence to gain insights into patriarchal society and the extent to which it oppressed women. 5 They proposed that lived experience differed from the rhetoric of rigid hierarchical relationships, problematising assumptions that violence was intrinsic to patriarchy. From the late 1990s, gender historians established that marital violence was less crude male domination than a response to challenges to men's masculine authority and

2 Ilana Gershon, 'Bruno Latour (1947-)' In Agamben to Zizek: Contemporary Critical Theorists. Edited by Jon Simons. Edinburgh University Press, 2010.

3 Roderick Phillips, Untying the Knot: A Short History of Divorce, Cambridge 1991, p. 102; Ellen Ross, "'Fierce Questions and Taunts": Married Life in Working-Class London, 18701914', Feminist Studies, 8:3, 575-602.

4 Wives could sue for separation on the grounds of cruelty through the ecclesiastical courts until 1857, and husbands could be brought before secular courts for breach of the peace and assault. For such legal recourse, and the progressive rejection of moderate correction, see Joanne Bailey [Begiato], 'Cruelty and Adultery: Offences against the Institution of Marriage' in Anne-Marie Kilday and David Nash (eds), Histories of Crime: Britain 1600-2000, Basingstoke, Palgrave MacMillan, 2010, 40-44.

5 For example, Susan Amussen, "'Being Stirred to Much Unquietness": Violence and Domestic Violence in Early Modern England' Journal of Women's History 6:2 (1994), pp. 70-89; Anna Clark, "Humanity or Justice? Wifebeating and the Law in the Eighteenth and Nineteenth Centuries' in Carol Smart (ed.), Regulating Womanhood: Historical Essays on Marriage, Motherhood and Sexuality, Routledge, 1992; James Hammerton, Cruelty and Companionship: Conflict in Nineteenth-Century Married Life, London, Routledge, 1992. 
standing; a troubling finding given that many men were increasingly unable to achieve the status of patriarchal manhood.6 Historians also scrutinised nineteenth-century marriage, divorce law, and the criminal justice system to show that the law courts' and their practitioners' gendered attitudes towards wife beating were further complicated by class and ethnicity.7 Recently, scholars have interrogated which acts contemporaries defined as cruel, and how they distinguished these from legitimate correction, and traced the role of print culture in exposing typologies of marital abuse. 8 All undermine a simplistic thesis of a 'civilising process,' by demonstrating that societies hold a range of conflicting views on which male acts of violence were deemed unacceptable.

There is, however, little research into marital violence from the new analytical perspectives of space, materiality, or emotions. Although the research surveyed above mentions

6 Joanne Bailey [Begiato], Unquiet Lives: Marriage and Marital Conflict in England c. 16601800, Cambridge, 2003; Elizabeth Foyster, Marital Violence: An English Family History, 16601857, New York: Cambridge University Press, 2005; Laura Gowing, Domestic Dangers:

Women, Words, and Sex in Early Modern London. Oxford: Clarendon Press, 1996; Margaret Hunt, 'Wife Beating, Domesticity, and Women's Independence in Eighteenth-Century London,' Gender and History 4.1 (1992): 10-33; Alexandra Shepard, Meanings of Manhood in Early Modem England, Oxford, 2003; John Tosh, A Man's Place: Masculinity and the Middle-Class Home in Victorian England, New Haven and London: Yale University Press, 1999. 7 Martin Wiener, Men of Blood: Violence, Manliness, and Criminal Justice in Victorian England, Cambridge, Cambridge University Press, 2004; Gail Savage, 'They Would if They Could: Class, Gender, and Popular Representation of English Divorce Litigation, 1858-1908', Journal of Family History 36(2):173-90.

8 Joanne Bailey [Begiato] and Loreen Giese, 'Marital cruelty: reconsidering lay attitudes in England, c. 1580 to 1850', The History of the Family 18 (2013), 289-305; Sara Butler, The Language of Abuse: Marital Violence in Later Medieval England. Leiden and Boston: Brill, 2007; Anne-Marie Hughes, The "Non-Criminal" Class: Wife-beating in Scotland (c. 1800-1949). Crime, History \& Societies, 14 (2), 2010, 31-54; Hannah Skoda, 'Violent Discipline or Disciplining Violence? Domestic Violence in Late Thirteenth- and Early Fourteenth-Century France. Cultural and Social History, 6 (1), 2009, 9-27; Lisa Surridge, Bleak Houses: Marital Violence in Victorian Fiction, Ohio, Ohio University Press, 2005. 
the location of marital violence in passing, it is only in the last decade that such issues have begun to be scrutinised. Broader studies of violence, for instance, chart how the built environment shaped inter-personal violence in the past.9 Work on domestic space also shows that the sexes inhabited rooms in gendered ways, determined by specific uses, the time of day, and prevailing social and cultural trends. 10 Not unexpectedly, such spatial complexity could create tensions between spouses.11 It is Fay Bound-Alberti who has developed this most explicitly in her 2003 analysis of eighteenth-century cruelty separation cases, which argues that 'household spaces became sites of conflict for a series of negotiations over the respective rights and obligations of spouses'. She observes that the material culture of marriage was thus loaded with political import; evident in the way that cruel husbands materially neglected wives, denied them goods, and excluded them from their domestic space by turning them out of doors. 12 In short, to use Bound-Alberti's words, 'The symbolic and functional lack of mutuality or kindness in marriage was concretised most fully not in blows or words, but in the physical structure and artefacts of the domestic environment'.13 It is surprising that her observations have not been developed further, given that the spatial and material 'turns' have enormous potential to illuminate marital abuse's cultural and social history.

In line with a multidisciplinary scholarship, this article contends that space and material

\footnotetext{
9 John Carter Wood, Violence and Crime in Nineteenth-century England: The Shadow of Our Refinement, London, Routledge, 2004, chapter 5. 10 For example Amanda Flather, Gender and Space in Early Modern England. Boydell \& Brewer, 2007; Jane Hamlett, Material Relations: Domestic Interiors and Middle-Class Families in England, 1850-1910, Manchester, 2010.

11 Flather, Gender and Space, p. 14, chapter 2.

12 Fay Bound, 'An "Uncivill" Culture: Marital Violence and Domestic Politics in York, c.1660c.1760' in M. Hallett and J. Rendall (eds), Eighteenth-Century York: Culture, Space and Society (York, 2003), p. 53.For material deprivation see Foyster, Marital Violence, pp. 46-53. 13 Bound, 'An "Uncivill" Culture', p. 53.
} 
culture are central to the way people and societies behave and perceive their worlds. Firstly, it is important to define terms. Daniel Miller's conceptualisation of 'materiality' is used, which relates objects, spaces, and people to each other.14 This is especially useful where intimate violence is concerned since the spatial and the material are rarely integrated by those who investigate it.15 It also deploys historical geographers' characterisation of space as referring to both physical surroundings and the impact that spatial configurations have on aspects of life.16 Overall, Bound-Alberti's argument is developed further, applying the thesis that spaces and objects do more than symbolise people and their concerns, they constitute meaning and behaviour.17 Karen Harvey acknowledges that historians trained to prioritise written documents as sources of information can struggle with the concept that 'stuff' has agency.18 Yet, there is a body of material culture scholarship which illustrates the deeper understanding gained from this approach. Jane Hamlett shows how the spatial organisation of the Victorian middle-class home shaped family relationships in terms of gender and authority. 19 Her other work demonstrates the ways in which the material world of mental asylums, middle-class schools, and lodging houses was used to control, cure, and civilise inmates. At the same time, these institutions' residents deployed such spaces for community, friendship, and solidarity; gaining some measure of

14 Daniel Miller, Stuff, Cambridge, Polity Press, 2010, Prologue.

${ }_{15}$ For the argument that the spatial and material should be considered together since they were closely combined see Hamlett, At Home in the Institution: Material Life in Asylums, Lodging Houses and Schools in Victorian and Edwardian England, Palgrave, 2015, p. 8.

16 Place is a subset of space, often dictating a focus on particular locales and their distinctiveness. For example see L R Pruitt, 'Place Matters: Domestic Violence and Rural Difference', Wisconsin Journal of Law, Gender \& Society 23 (2008) 347.

17 Miller Stuff, 11, 21, 40 and passim.

18 The contributions to this edited volume show the creativity resulting from historians attending to materiality. Karen Harvey (ed), History and Material Culture: A Student's Guide to Approaching Alternative Sources, Routledge, 2010, p. 7, and 'Introduction: Practical Matters'. 19 Jane Hamlett, Material Relations, passim. 
empowerment through their use of decoration. 20 The expanding study of emotional objects goes even further by demonstrating that places and objects act as vessels for emotions, or can be ascribed a range of emotions which construct relationships, practices, and identities.21 As Sherry Turkle points out, evocative objects are 'provocations to thought,' as well as, it is shown in this article, action, since what emerges in the research presented here is that the diverse spaces and things identified with marital violence had emotional potency which acted upon individuals and society. 22

To investigate the role of materiality in marital violence, this article surveys a representative example of law suits and court cases centring on spousal violence from around 1700 to 1857, when the Matrimonial Causes Act introduced the Divorce Court and legal procedures for obtaining separation and divorce changed. Around 200 cases were examined, including cruelty separation cases initiated in the ecclesiastical courts in Durham and York,

20 Jane Hamlett, At Home in the Institution, pp. 6, 7, 10 and passim.

21 For an excellent overview of this emerging field see Stephanie Downes, Sally Holloway and Sarah Randles, 'A Feeling for Things, Past and Present' in idem (eds) Feeling Things Objects and Emotions through History, Oxford, Oxford University Press, forthcoming 2017. Textiles are an object often explored in this way, for example: Catherine Harper, 'Sex, Birth and Nurture Unto Death: Patching Together Quilted Bed Covers' in Anna Moran and Sorcha O’Brien, Emotion, Design and Material Culture, London, Bloomsbury, 2014, pp. 31-40. Three nineteenthcentury objects (portable writing slate, plaster cast clasped hands, and a divination basket) are briefly examined as representing grief, love and suffering that shaped people's feelings of those who view or interact with them, Laurel Thatcher Ulrich, Ivan Gaskell, Sarah J Schechner, and Sarah Anne Carter, Tangible Things: Making History Through Objects, Oxford, Oxford University Press, 2015, p. 164-172.

22 Sherry Turkle (ed.), Evocative Objects: Things we Think With, MIT Press, 2011, p. 5.

Literature on this is only emerging recently. See for example Alice Dolan and Sally Holloway, Emotional Objects: Touching Emotions in History Website and Blog: https://emotionalobjects.wordpress.com/about/ (Accessed 09 Apr. 15); Histories of Emotion $B l o g$, 'Feeling Things: Objects and Emotions in History Symposium' http://historiesofemotion.com/2013/03/06/feeling-things-objects-and-emotions-inhistory/(Accessed 09 Apr. 15) 
breaches of the peace heard by quarter sessions in Buckinghamshire, Oxfordshire, Northumberland, and Yorkshire, and manslaughter and murder cases prosecuted at the Old Bailey, London.23 The cases are selected because the spouses involved in them came from a wide range of social classes, including working-class men prosecuted at the Old Bailey, poor and better off wives who visited magistrates, and middle-class litigants who sought separation suits on the grounds of cruelty and spanned the middling spectrum from modest to wealthy. It thus includes spouses from a range of household types: single- and multi-family occupancy and those containing numerous domestic goods as well as those with only a bare minimum. The litigants and witnesses frequently described the location, acts, and types of violence and implements used. The specific ownership of goods according to wealth and class and era is not inventoried since this level of detail is not available. Instead, the accounts of space and objects were collected and analysed within a cultural history framework, which intends to access the meanings of marital violence and their consequences for behaviour and attitudes. Nonetheless, this range of class representation and lengthy time frame allows for evaluation across different types of household in an era which saw significant shifts in dwelling styles and access to consumer products.

For all the differences in the amount of space inhabited and the number of domestic objects within the dwellings of the couples investigated, there were significant commonalities. Firstly, marital violence 'was temporally and spatially fluid' since men abused wives over long periods of time and throughout several rooms, including bedrooms, kitchens, sitting rooms and dining rooms, as well as stairs and passages, and in their yards and gardens, in dwellings ranging

23 Some of the same source base was used in my earlier studies of marriage and marital conflict, but was re-examined and supplemented with additional cases to extend the period investigated. For a more detailed account of the sources see Bailey, Unquiet Lives, pp. 207-222; also Bailey and Giese, 'Marital cruelty' and Joanne Bailey [Begiato], '"I dye [sic] by Inches": Locating Wife 
from shared lodgings to single households.24 Some marital violence occurred in the streets and quasi-public spaces as well; especially public houses for working-class couples, since conflict occurred over expenditure and alcohol. In 1841 two witnesses reported seeing Edward and Frances Studd walking down Old King Street, halting on the pavement opposite the King's Arms public-house where Edward hit Frances on the head so that she fell into the road. On getting up, they walked parallel on the street and in the middle of the road for about twenty yards, until he offered to hit her again and went into the Cheroot public-house.25 However, if marital abuse began in or near a pub, it was not seen as the appropriate place for its continuation. In 1841 Hannah Wilson, the wife of the landlord of the Red Lion and Spread Eagle public-houses in Whitechapel, testified about a quarrel between Ann and William Bradford over a pawnbroker's ticket. When William stopped his wife swearing at him by pushing her over, Hannah reported that she warned him: "You shan't ill-treat her in my shop, and if you want to quarrel, go home"".26 Thus, for the most part, homes were the location of marital violence.

Secondly, whether a dwelling was a large house inhabited by one family or a lodgings house divided up into numerous rooms each containing a family, marital abuse was almost never invisible. In the former servants and family members saw and heard abuse and in the latter other household members did.27 Thirdly, across all households violence often occurred in two 'spaces' which were both ambiguous and contested: beds and stairs. Fourthly, there were similar types of

Beating in the Concept of a Privatisation of Marriage and Violence in Eighteenth-Century England' Social History, 31 (3), 2006, 273-294.

2474 per cent of 172 cases examined Bailey, "I dye [sic] by Inches".

25 Frances later died from head injuries sustained in falling. Edward was found not guilty of manslaughter. Old Bailey Proceedings, Edward Studd, Killing, manslaughter, 23rd August 1841. Reference Number: t18410823-2282 ${ }_{26}$ OBP, William Bradford, Killing, manslaughter, 23rd August 1841. Reference Number: t18410823-2044 
domestic objects that were associated with wife beating across social classes. Finally, when marital abuse was imagined in various kinds of print culture it was conveyed through the disruption of household space and objects, regardless of class. However, some contrasts are also revealed. Discussions of marital violence in the nineteenth century were increasingly distinguished by social class, with the mistaken notion emerging that middle-class men's abuse of their wives was predominantly mental and emotional, while working-class men's was physical. In this process, the materiality of wife beating was increasingly perceived to be classrelated too.

\section{Placing Marital Violence in its Spaces}

The location of violence had a constitutive role in perpetrators' and victims' behaviour. Our environment habituates us to societal and cultural expectations; as Daniel Miller observes, for example, 'housing implicates contours of power and scale that make such intimate issues as our personal relationships often contingent upon much grander forces'.28 Where spousal relations were concerned, the grander force was patriarchy, which structured the union, its terms, and its material dimensions. The separation, quarter sessions, and Old Bailey cases surveyed here offer disturbing evidence of the way the patriarchal domestic space of the home facilitated forms of abuse, which can be assigned to three categories: violent husbands excluding wives from dwellings, attacking or confining them in various rooms, and wives using domestic space for retreat and protection.

At the most general level, couples' use of dwelling space represented to onlookers (and law court) the state of their relationship. Susey and David Smirthwaite's eighteen-year old

${ }_{27}$ Bailey, "I dye [sic] by Inches"', Foyster, Marital Violence, chapter 4. 
servant, Ann Hemingway, deposed that when they employed her in 1830, David refused to sleep with his wife, leaving her alone in the parlour while he sat in the kitchen with the servants; when she came to the kitchen he sat in the parlour.29 This evidence demonstrated David's failure as a husband, alongside that of his physical abuse and improper suggestions to female servants. More specifically, as Bound-Alberti observes, descriptions reveal the centrality of dwelling space to the enactment of marital violence. In all three categories outlined, domestic spaces heightened tension and encouraged spouses, particularly husbands, to assert physical and metaphorical dominance.

Abusive husbands turned wives out of their home. To some extent, this had a legal function since it proved to the courts that a woman had left her home due to her husband's abuse and thus ensured her right to maintenance, which she was denied if she departed voluntarily. However, the examples suggest that men ejected their wives as acts of domination over them and their domestic environment, typically expelling wives from spaces in which they held authority as sites of familial and life-cycle power. This consistent feature of marital conflict cases, carried out by both middle- and working-class husbands, differed only in that higher status men ejected wives from the front or back door into the street or yard, while working-class men living in shared lodgings pushed their wives out of their room's door onto the landing.

There are also class differences evident in the second category, wherein husbands denied wives access to specific areas of the home, or confined them in rooms, attics, or basements. Working-class men only had mastery over the one or two rooms in which they and their families lodged. Middle-class men could be more imaginative with the space they sought to control.

28 Miller, Stuff, p. 51, quote from 80.

29 Borthwick Institute of Historical Research [hereafter BIHR], CONS.CP.1831/5 Susey Smirthwaite v. David Smirthwaite. 
When Catherine married Robert Warburton in 1792, she brought moveable goods and a farm to their union. By the time she sued him on the grounds of cruelty in 1800 , he had confined her in the farm's small cottage and the farm itself for several months at a time. In 1798 he then detained her in the unheated garret of a town house in Pontefract for six days until friends rescued her. All this was designed to force her to sign over to him her separate property.30 The 1837 case against the Royal Navy Surgeon James Veitch reveals that he confined his wife to their home for three weeks after her mother's death, simply by locking the front door.31 Some cases were even more sinister. Mary Godmont alleged that her husband, a gentleman from Sculcoates, not only refused to live with her or render her conjugal rights, he had her seized and confined in a Parish workhouse. When released, she still required his maintenance, and in retaliation against being forced to support her, he placed her 'under severe and strict confinement in his House for a period of sixteen months - by his beating ...[her] during such confinement sometimes with his hands sometimes with sticks and sometimes with whips' and denied her wholesome food and decent clothing. Throughout, he transgressed matrimonial conventions by preventing her managing his household and making her do the work of a menial servant. 32

It is useful in such cases to apply the concept of 'geographies of fear', in which certain spaces move from neutral sites to ones charged with emotion.33 Geographers reveal that attitudes towards space and place are mutable depending on what is experienced in them. Simon Springer, for example, explains that the experience of domestic violence transforms an 'objective house'

30 BIHR, Cons.CP 1800/3, Warburton c Warburton, 1800.

${ }_{31}$ Cited in Foyster, Marital Cruelty, p. 30.

32 BIHR, Cons. CP. 1833/5 Mary Godmond v. Samuel Hall Godmond, 1833. 33 Molly Warrington, (2001), 'I must get out': the geographies of domestic violence. Transactions of the Institute of British Geographers, 26: 366. 
from a place of sanctuary to a place of terror for the individual concerned.34 This can be seen throughout the cases studied and particularly in the third category when abusive husbands pursued wives through dwellings or shared lodgings, forcing them to take refuge in other rooms. Again the particulars of the space varied with social class. Urban working-class wives in lodgings were unable to take refuge within the limited space available, but used the stairs and landings to flee onto the street, or to take sanctuary in neighbours' rooms. When Robert Williamson, a Chelsea Pensioner, struck his wife on the head with a poker in their room in Royal Hospital Row, in 1842, she staggered onto the stairs to call a neighbour who lived on the floor below. Margaret Doolen responded by giving the bleeding Sarah Williamson asylum in her room before taking her to a doctor. 35 Wealthier wives sought safety in servants' spaces. In 1845, Mary Bentley's ran to the cellar to escape her husband, a brewer, who drunkenly returned home late, swore at her, and struck her with such violence that her combs fell out of her hair and her brooch was broken. 36

Peter Taylor proposes that homes can thus be both a haven and a cage, depending upon factors such as age and gender: to which we can add wealth.37 This was perhaps especially so for better-off middle-class women who lived in dwellings with several rooms. In the 1770s Francis Spence, a gentleman of Ripon, Yorkshire, for example, not only confined his wife in her Bedchamber, 'by beating and threatning [sic] to Kill her ... [he] did frequently terrify and alarm

\footnotetext{
34 Simon Springer, S. 2011. Violence sits in places? Cultural practice, neoliberal rationalism, and virulent imaginative geographies. Political Geography. 30 (2), 90-98.

35 OBP, Robert Williamson, Killing, murder, 28th November 1842. Reference Number: t18421128-40

36 BIHR, Cons. CP 1847/4 Bentley v Bentley, 1845.

37 Peter Taylor, 'Havens and Cages: Reinventing States and Households in the Modern WorldSystem', Journal of World-Systems Research, vi, 2, Summer/fall 2000, 544-562 Special Issue: Festchrift for Immanuel Wallerstein,Part I.
} 
her so much that she was obliged to keep her Room Door locked for several Months together'.38 Elizabeth's room was both a prison and a retreat. So too was it for the pregnant Margaret Lees who in 1796 locked herself into a room after her husband, a Manchester warehouse owner, got drunk and violent, then retreated further into a closet as he proceeded to break down both doors with a mattock.39 As the form of dwellings has changed over time, so have areas for hiding. Charlotte Bostock, living in Kennington, South London, for example, 'stayed entirely in the nursery with her children' in 1848 when her husband, a retail druggist, was violent towards her. Such specialised areas for children were an innovation of the early nineteenth century.40 By the twentieth and twenty-first centuries the place of 'safety' for women is more likely to be the bathroom which has a lock on the door.

Feminist geographers define the modern home 'as a gendered landscape', and a contested space because in it men's authority is pitted against women's.41 The spatial dimensions of marital violence outlined above show that similar tensions are evident in homes of the past, perhaps more so given that patriarchy explicitly structured household forms as well as relationships. Men had mastery over their dependents: wife, children, and servants. Wives' duties included managing children, maids, the household and its provisions. As Flather points out, both spouses thus 'used space to assert authority ... over the use and organisation of their own homes'.42 This had potential for conflict since either might feel justified in seeking to control and defend their areas of influence, especially over shared spaces. Records of matrimonial problems

\footnotetext{
38 BIHR, CP/I 2013, Spence c. Spence

39 BIHR, Chanc.CP 1803/3 Lees c Lees, Deposition of Hannah Seddon, their servant. A mattock is an agricultural hand-tool that resembles a pick-axe.

40 Cited in Hammerton, A. J. (1992). Cruelty and Companionship: Conflict in NineteenthCentury Married Life. New York and London: Routledge, p. 82.

41 Warrington, 'I must get out', 369.

42 Flather, Gender and Space, pp. 14, 42-60
} 
certainly reveal that conflict catalysed around the government of household and servants.43 Moreover, accounts of marital violence indicate that certain spaces were hot-spots of violence. Of course, this varied with class, wealth, and era as dwelling arrangements altered over time and rooms became more specialised. Wealthier women, for example, were less likely than middleclass counterparts to be attacked in kitchen areas since their servants prepared food. Regardless of the amount of space available, however, the marital bed as well as stairs and landings were particularly associated with marital violence. The next section explores these sites of contestation.

\section{Contested Sites and Marital Abuse}

To some extent, it was tensions caused by unclear role- and spatial- boundaries that can be witnessed in violence that occurred around the bed and the stairs. In the eighteenth and nineteenth centuries the bed was not a private space in any social class, due to its centrality to a number of life-cycle functions related to childbed, sickbed, and deathbed. In working-class homes, beds were unlikely to offer much in the way of privacy, since couples might live in one room, shared with children or other adults. A manslaughter case heard at the Old Bailey in 1846, reveals that Jeremiah and Mary Williams shared their room in a house in Queen Street, Seven Dials with two women. The Williams slept in one bed, the two women in another. On the night in question, when Mary Williams was fatally injured, she drunkenly returned to her home at 10 $\mathrm{pm}$ and the two women testified to hearing her quarrel with her husband. They also saw him rise from the marital bed to knock her out of the chair where she sat alongside it, then kick her, and try to force her to lie on the bed. Even so, neither could testify as to which spouse threw an iron

43 Bailey, Unquiet Lives, chapter 4. 
candlestick at the other in the bed, since by then the light was out.44 In wealthier, larger households, heavy textiles were used to enclose the bed space from a chamber shared with servants and children, and thus facilitated marital sex and conversation. 45 The corollary was that spouses might fight in these spaces too.

As Bound-Alberti comments, beds became sites of marital tensions because they transitioned from a sexual to an asexual space; multi-functional, they were re-purposed for conversation, sociability, marital sex, illicit sex, sickness, birth, and death.46 The convergence within the bed of various activities, emotions, and symbolic meaning could be toxic. Several husbands were described aggressively forcing wives out of the marital bed. In 1717, Jonathan Bowes, a farmer from County Durham, pulled his wife out of bed, shouted obscenities at her and forbid her to lie in bed with him ever again during his life.47 Most of John Smith's attacks on his wife in the 1730s-40s occurred in the marital bed; on one horrific night he knelt on her chest and attempted to suffocate her. Her only recourse was to escape to a garret bed, sometimes with their maid.48 Beds were also hotspots for violence because a husband would return late to the house and attack his wife as punishment for some earlier perceived 'infringement'. Jane Allison alleged that her husband, Charles, a Master Mariner, of Tynemouth, returned home the week after Christmas in 1764 , at about $11 \mathrm{pm}$, and dragged her out of bed to stand in a cold passage in only

44 OBP, Jeremiah Williams, Killing, manslaughter, 17th August 1846. Reference Number: t18460817-1598a $45 \mathrm{~J}$. Bailey and A. McShane (2010) 'Beds and the making of the domestic landscape', unpublished paper given at 'The Body in Bed' Seminar Series, Royal Holloway, London; Sara Pennell, 'Making the Bed in later Stuart and Georgian England', in Jon Stobart and Bruno Blonde (eds.), Selling Textiles in the Long Eighteenth Century, Comparative Perspectives from Western Europe, 2014.

46 Bound, 'An "Uncivill" Culture p. 55.

${ }_{47}$ University of Durham, University Library, [Hereafter UOD] DDR/EJ/PR C/2/1717/2 Esther Bowes v. Jonathan Bowes, 1717 
her nightclothes. She said he was angry because Jane had refused to accompany him to visit his daughter.49 He defended his actions by explaining that he only demanded she leave the marital bed when she used scandalous language against his adult children; his usual habit was to leave the bed and wander the streets for peace.

As this indicates, the bed was a space over which spouses sought to exert marital control. The descriptions of Joseph Bentley's violence show that it was often enacted around or upon the bed. On 6 April 1844, Mary Bentley and her cousin gave up waiting for Joseph's return home, and each retired to her bed. When the drunken Joseph came to Mary's bedside in the early hours, swearing and insisting she rose, she fled to her cousin's bed. Joseph followed, threatening to pull her out of bed and tear-off the hangings if she did not get up. Both women were terrified and for good reason; when Mary got up Joseph hit her with 'clenched or doubled fist' on her face and body. A year later in October 1845, he seized Mary by the shoulders in front of their servants and forced her to go to bed very early. Before she got up the following morning, he flew into a violent passion over a gig harness which he accused her of giving to the servant man to hide. In the presence of a servant, he slapped Mary in the face and dragged her from the bed by the feet. Joseph Bentley used extreme violence not only to subordinate his wife, but to reassert his power over the household and its servants, which he perceived Mary to threaten.50

The bed as a focus of spousal struggle was played out somewhat differently in very poor households. William Bradford was convicted of manslaughter at the Old Bailey after he knocked his elderly wife over and she died as a result of her injuries in 1841. The couple fought over the ownership of the marital bed on the night William attacked his wife. The pawnbroker John

48 UOD, DDR/EJ/PRC/2/1743/12 Susannah Smith v John Smith 1743

49 UOD, DDR/EJ/CCD/3/1765/2 Jane Allison c Charles Allison, 1765.

50 BIHR, Cons. CP 1847/4 Bentley v Bentley, 1845 
William Fryett testified that Bradford came to his shop on the 3rd of August, about four o'clock in the afternoon, followed shortly after by a woman: 'he was offering something in a pillow-case or bag in pawn-I do not know the contents, for the woman desired us not to serve him'. The Bradfords left the shop arguing, and Fryett saw William spit repeatedly in her face, wring her nose, and strike her. The bag was apparently bedding, as William Wagg, a shop-man in another pawnbrokers testified. For Bradford next offered him 'a bed in pawn.' While Bradford agreed to Wagg's offer of money for the bed, his wife entered and said, '"Don't take that bed in — it is my property-he is a rogue, and has robbed me". Wagg sent for a policeman when Bradford retaliated by back-handing her twice across the mouth.51Although of far less value than wealthier couples' beds, this bed linen was a source of dispute over ownership.

Stairs were another regular site of violence in reports of marital violence. An instrumental explanation for this is that victims of abuse selected the worst examples of violence that they experienced in their litigation, to obtain the best chance at success in getting a separation or divorce granted. Being thrown downstairs was such an instance, probably because, as the examples show, the opportunities for injury were so high. When Elizabeth Finch sought to separate from Samuel Finch in 1779, she presented an undated note as evidence, which stated that she was his fourth wife and that he had hastened his other wives to their deaths through illusage; throwing one wife downstairs so that she broke her back.52 The act was thus an unambiguous example of cruelty rather than corrective behaviour as Elizabeth Spence's allegation about her husband indicates: he would 'place himself upon the stairs with a Penknife in

51 OBP, William Bradford, Killing, manslaughter, 23rd August 1841. Reference Number: t18410823-2044 52 BIHR, Trans.CP.1779/1, Finch c. Finch, 1779. 
one hand and a Hatchet in the other and threaten to do for or Kill' her.53 Similarly, when Catherine Warburton refused to sign over some of her money to her husband, in 1798, he seized 'her in his Arms and forcibly dragged her up Stairs to the first landing where in great rage he threw her down'. He ordered her up the next set of stairs into the garret where he locked her for several days.54 No husband or his defence could present such incidents as 'reasonable chastisement'.

There is more to be investigated, however. In the first place, the physical location of the stairs itself shaped the violence occurring there. William Rogers, a clothier of Holbeck, for example, beat his wife Betty unmercifully on the night of 2 April, 1787.55 In throwing her down stairs at midnight, it is clear that violence had originated elsewhere, such as a first-floor bed chamber, and then spilled over into stairs and landings because they were points of communication between rooms. Stairs were also a point of egress, so when husbands ejected wives, or the women fled, further abuse occurred on the landing and stairs. This is particularly prevalent in multi-resident lodgings houses. Catherine Davis, a resident of Bainbridge-Street, St. Giles's, lived in a room adjoining that of Michael and Ellen Ragan. In 1842 she was going up stairs to her room and:

saw them inside the door quarrelling - they were both very drunk indeed - the wife was holding the handle of the door — she would not go in — the prisoner was persuading her to come in, several times, and at last he caught hold of her arm to pull her in, and gave her two or three slaps on the head with his open hand - he then let go of her-she staggered and fell within a foot of the stairs - he then gave her a kick on the back, and threw her

53 BIHR, CP/I 2013, Spence c. Spence. For an earlier example, see BIHR, CP.H/3469, Smithson c. Smithson, 1680.

54 BIHR, CP.I.2503, Catherine Warburton v. Robert Warburton, 1799 
down stairs. 56

In some ways, stairs spatially symbolised wives' potential for independence from their husbands and thus may have been sites that especially antagonised controlling husbands. This might explain James Lees' refusal to let his wife, Elizabeth, leave an upstairs room in April 1797. The other evidence suggests that this cotton manufacturer of Saddleworth was a particularly domineering husband and his act may have been related to her having given birth a couple of weeks previously. He may have wished her to keep more fully to her lying-in period. When she insisted on leaving the room and go downstairs, he 'with great violence pushed her as she was passing him and said "Damn thee go thy way" whereupon she fell from the top of the .. stairs to the bottom'. 57

Stairs were generally considered a public space, where there was less expectation of privacy, open to servants and family members, or to other householders in shared dwellings. Thus, both elite and non-elite women made for these public spaces when experiencing violence because the physical transitional space of stairs offered areas where women might seek aid from neighbours, servants, or family members. Elizabeth Smith, the wife of Samuel Smith, a tailor, lived in the same house as Miles Phillips and his wife Sarah, for four years. On Boxing Day, 1847 she immediately responded to her neighbour Sarah crying out: "You murdering villain, you have been trying at this for years, and I suppose you have done it for me at last." Taking a candle, she used the landing and stairs to monitor what was happening. 58 Similarly, Mart Collins joined other neighbours in the stair well in 1842, on the night that Michael Ragan attacked his

55 BIHR, CP.I.2305, Elizabeth Rogers v. William Rogers, 1793

56 OBP, Michael Ragan, Killing, manslaughter, 19th September 1842. Reference Number: t18420919-2691 57 BIHR, Chanc.CP 1803/3 Lees c Lees 
wife. Mart remembered: 'I was on the banisters, and looked over-she fell to the bottom of the stairs — there was a great crowd of people—when he kicked her'.59

Although stairs were communal, their spaces was not neutral, sometimes sites of powerful emotions. Joseph Dalchon, who kept a lodgings house in London, and his wife's job was to light inhabitants and visitors up and down the stairs in the evenings. On the night in 1847 that Henry Harrison punched his wife to the floor on the landing outside their room, Elizabeth Dalchon had lit him up to his room, and did the same for his wife when she returned. Later again in the evening, she lit Ann Harrison, and another woman who lodged there, up the stairs to deposit food shopping. When a neighbour went for the police to assist Ann, Elizabeth waited downstairs. She testified in the ensuing manslaughter case: 'I do not know why I did not go up stairs - I stood by the parlour-door'. For the remainder of the night she often stood at the bottom of the stairs, hearing what unfolded in the room above. Although the lodgings stairs were to some extent her normal domain, by this point they were transformed into a place of fear for her as well as those directly involved in the marital violence. 60

Secondly, stairs symbolised social household hierarchies, as captured in the phrase 'below stairs', which conveys the status division between the elite and their servants. Similarly, they represented the connections and divisions between the differently gendered spaces of the house.61 Attention has been drawn to this for some time. For example, Pierre Bourdieu's

58 OBP, Miles Phillips, Killing, manslaughter, 1st February 1847. Reference Number: t18470201-614 59 OBP, Michael Ragan, Killing, manslaughter, 19th September 1842. Reference Number: t18420919-2691 ${ }_{60}$ OBP, Henry Jones Harrison, Killing, murder, 14th June 1847. Reference Number: t184706141389

61 The ubiquity and familiarity of material culture can be part of what makes it more powerful in shaping behaviour and expectations. Miller, Stuff, p. 50. 
anthropological exploration of the Berber house suggested that such homes symbolized gender hierarchies:

The low and dark part of the house is also opposed to the high part as the feminine to the masculine: besides the fact that the division of work between the sexes, which is based upon the same principle of division as the organization of space, entrusts to the woman the responsibility of most objects which belong to the dark part of the house - watertransport, and the carrying of wood and manure, for instance - the opposition between the upper part and the lower part reproduces within the space of the house the opposition set up between the inside and the outside. 62

This interpretational framework can easily be applied to the middle-class men who forced their wives into parts of the household deemed lower, less important quarters, due to their association with the feminine. In this sense violence on stairs was not simply an 'accidental' location resulting from men pursuing their wives through a house. As Bound-Alberti contends, the 'household was not a neutral structure, but a series of politicised spaces, each of which was invested with particular emotions and psychological resonance'.63 In the context of work on 'geographies of fear,' such men were exerting their dominance not only physically, but metaphorically too: the stairs were shaping these men's thoughts and actions.

\section{Placing Objects in Marital Violence}

This section surveys the things used to enact marital violence and their meanings. Though a man's body in the form of fists and feet was the primary mode of carrying out violence, a

62 Cited in Tim Dant, Material Culture in the Social World. Open University Press: Buckingham 1999, pp. 65-6.

63 Bound, 'An "Uncivill" Culture', p. 54. For gender and power expressed through the decoration 
variety of objects were used as weapons, including mundane domestic things, occupational tools, and symbols of discipline, alongside the obvious weapons like swords and guns. 64 Considering the physicality of objects of marital violence prevents us treating marital violence too abstractly, forcing us to consider their properties and therefore the fleshly damage they caused. The two hundred cases investigated included a wooden charger, stoneware plate, tankard, burning coals, lit candelabra, and a chair, as well as stick-like implements such as: bed staff, poker, hearth brush and other hearth implements, umbrella, walking stick, whip, and in one case, a bull's pizzle (a bull's penis, dried and twisted into a switch). Consider what these objects reveal about being beaten by one's husband who in a patriarchal world, let us remember, was supposed to be a wife's protector, guide, companion, and lover. A pewter tanker, an iron poker, a silver or brass candlestick share several qualities: they are heavy, likely to draw blood if used as a weapon, and even to kill the victim depending on which part of a body they struck. In conveying the victims' fear and pain, the material culture of violence also offers insights into the way society and law judged accused husbands.

If at first glance some objects appear to be a disciplinary instrument, considering the objects' materiality demonstrates that they were far too brutal to fit into a framework of lawful chastisement. Thomas Bowes of Brancepeth used his 'iron beef forks' in the 1730s to try and stab his wife until the servant intervened and took them off him.65 When Elizabeth Bowes brought her cruelty separation case to Durham Consistory Court against him in 1737 she claimed that he 'kept a large iron poker' with the intent to kill, slay or wound her; on one occasion beating her

and furnishings of the home see Miller, Stuff, p. 89.

64 Swords and pistols were used, but these are not discussed here since they were objects designed for the purpose of violence.

65 BIHR, Trans CP 1737/2 Elizabeth Bowes c Thomas Bowes, Libel. 
with it so that her whole body was bruised and she bled at the mouth.66 This was critical in law, showing that these objects were not corrective in function but deployed in uncontrolled anger, mild chastisement's antithesis. In addition their use was grossly out of proportion to any supposed female provocation. When Jane Gibson sued her husband, Edward Gibson, an iron founder of Great Driffield, in 1851, she described coming home from a funeral, about 9pm on 6 March 1840. Edward immediately ordered her to turn out her pockets, counted the money and said she had sixpence more than she should, which he accused her of obtaining by whoring. Grasping a poker he struck her on the head so that she staggered a few yards till she fell on the floor.67 As James Hammerton suggests in his study of Victorian wife-beating, men simply picked up 'the most easily available weapon;' they did not select a tool of corporal punishment.68 Material culture thus offered hard evidence of irrational violence, quick temper, sudden and impromptu acts of marital abuse.

The material stuff of marital abuse also exposes how central the attempt to assert dominance over a spouse is in acts of abuse. This insight extends to the few cases of women accused of violence against husbands. In 1729 James Currie, a Carlisle curate, defended himself against his wife's accusations of cruelty by counter accusing her of violence. He said that when he was ill she was so infuriated by the doctor declaring that James was recovering that she 'took up a large Poaker and without any Provocation given her by him ... heaved it up above her head with Design ... to Strike and Knock' him down. His niece intervened by catching hold of the poker. Later, Jane threw two brass candlesticks with burning candles at James resting in bed with

66 BIHR, Trans CP 1737/2 Elizabeth Bowes c Thomas Bowes, Libel.

67 Cons. CP 1851/1, Gibson c. Gibson.

68 Hammerton, Cruelty and Companionship, p. 112. 
his children after a journey.69 Neighbours deposed to the church court that the couple had married for convenience since both were widowed and James had small children; they judged the union conflictual because Jane did not love James and refused to be subordinate. Jane's use of these objects suggests the truth of their assessment. In most cases, it was husbands who sought to exert domination by wielding an implement. Thus William Ellerby, a North Yorkshire yeoman, used a horsewhip to strike and threaten his wife in 1833.70 This was shaped by the convenience of what was to hand, no doubt, but they were all objects used to subordinate or discipline animals or break their will. As Ann Ambler, spinster, 59, of Wakefield, astutely commented in December 1831, David Smirthwaite, who attacked his wife with shoes, dishes, and fists, was a man 'that will have his own way.' 71

Husbands enacted their power through domestic objects in another form, exemplified in reports of their destruction of an array of domestic objects in the home. This was not only to intimidate. In May 1847, Sarah Jones returned from market with Ann Harrison to the house they both lived in and helped Ann place her purchases of food on the table. Alongside was seated her husband, Henry, apparently asleep. Immediately, Sarah remembered, 'he got up - he never spoke a syllable, nor she either, but he flung the things out of the window'. The menace of his action is quite clear, as was his intention to impose his command over the domestic environment.72 In another case from 1842, Margaret Doolen took Sarah Williamson to the doctor when her husband, Robert, hit her. John, Margaret's husband, stayed at home and within ten minutes he 'overheard a noise like the breaking of crockery' from the Williamsons' room above. Having

69 BIHR, Trans.CP 1730/6 Currie c. Currie.

70 Cons.CP 1846/1 Mary Stephenson Ellerby, Newbiggin Hall, Egton, v. William Ellerby, West Barnby, parish of Lyth, yeoman. 1846 71 BIHR, CONS.CP.1831/5 Susey Smirthwaite v. David Smirthwaite. 
already hit his wife twice with a poker, Robert destroyed the domestic stuff of their lives while she received medical assistance. Robert then left for the Coach and Horses pub opposite, returning five minutes later, when John Doolen heard him smash more crockery and overheard him say: "I will let them see who is master in this house"". This telling remark indicates that he endeavoured to stamp his authority on his environment as well as his wife's body. Esther Tanner, Sarah's adult daughter, who lived with her mother and step-father, also testified that on returning to their lodgings' room, she found the

'middle of the stairs from Mrs. Doolen's room to my mother's was very bloody-I went into the room, and found the things broken about the room, all the crockery ware- the bed was taken off the bedstead, and put on the ground, and water appeared to have been thrown all over it - the plates, dishes, and every thing were broken to pieces — when I left in the morning the usual fire-irons were there-I could not find the poker in the evening, but it was there, for I found it on the Friday morning, laying on the hearth, and the crockery ware all on the top of it'.

Robert had enacted his violence through the domestic objects that constructed the dwelling, attacking the bed, the table-ware and converting the fire-iron into a deadly weapon.73 The domestic objects were not simply an extension of Sarah's body, or a substitute upon which he took out his anger; they were also the target of his violence.

Historians of wife beating have identified the causes of male abuse in women's inadequacy carrying out husbands' demands, or their refusal to perform domestic tasks, which often related to the material culture of home life. For example Thomas Marlin allegedly pushed

72 OBP, Henry Jones Harrison, Killing > murder, 14th June 1847. Reference Number: t18470614-1389 
his wife Mary down the very steep loft stairs in the mews in which they lived in 1847 . Their daughter, Maria, reported that her mother had asked Thomas for beer money; when he refused Mary retaliated by denying him the oil he had requested 'and ran away with the vinegar-cruet in her hand'. Maria saw her mother running past the door at the top of the stairs and Thomas 'following her, a few steps behind.' Hearing Mary scream, she rushed out to found her lying at the bottom of the stairs. 74 Examining this from the perspective of the material culture of marital violence moves beyond a simplistic assessment of causality and helps differentiate the trigger from the cause of marital abuse. The latter was far more complex than a wife's inability or refusal to perform a task, embedded as it was in a hierarchical, gendered spousal relationship. But more than this, it shows that acts of violence flowed from husband to wife through domestic stuff.

One can go the next step to argue that men conflated wives with domestic objects so that the latter also inspired men to acts of physical force. For instance, men's attacks often occurred when women were busy at domestic tasks. In 1743 Henry Giles attacked his wife Mary when she was sitting spinning with her daughter from a previous marriage. He threatened Mary with an axe, and then used it to break the daughter's wheel.75 When Mary Bentley was sewing with her friend Elizabeth Atkinson on the afternoon of 9 September 1845, her husband entered and snatched the sewing from her hand, throwing it onto the fire. He seized hold of the work table at which the woman sat, hurled it to the floor, picked up one of its broken legs and menaced his wife with it.76 It is not enough to say that the timing of such attacks upon women working and

73 OBP, Robert Williamson, Killing, murder, 28th November 1842. Reference Number: t18421128-40

74 Thomas Marlin, Killing, manslaughter, 14th June 1847. Reference Number: t18470614-1359a 75 UOD, DDR/EJ/PRC/2/1744/11 Mary Giles v Henry Giles (Hexham) 1744.

76 Cons. CP 1847/4 Mary Bentley, v. Joseph Bentley. 
socialising was coincidental. Husbands deliberately destroyed objects women owned and used because they recognised the women's physical and emotional investment in them. In doing so, these men articulated their anger, domination, and mastery over wives and their household objects.

Generally, the things involved in acts of abuse were ordinary. The objects that men hit their wives with, or destroyed, were mundane. When husbands materially deprived their wives, moreover, they denied them basic necessities: food and clothing. Yet, it is helpful to think of such objects as emotional artefacts as well. Refusing to provide wives and families with their material rights was not only a statement that a husband rejected his legal obligation, when his primary function was provision; by withholding this 'stuff' he refused his marital love too. Certain objects implicated in marital violence had enormous emotional resonance. For example, an especially symbolic form of abuse reported in nineteenth-century cases was the husband tearing off his wife's wedding ring as part of an attack, often before turning her out of the house. On 6 March 1833 William Ellerby accompanied his wife, Mary Ellerby, home from her father's house. Enroute he pushed her down, brutally tore off her wedding ring and declared he would be her butcher.77 In 1845, Joseph Bentley came home to his wife in a raging temper and ordered their servant girl who was setting the table to go to the local joiners in Shepley for his file so he could file his wife's wedding ring off. 78 These were intense rejections of marital love.

There were other emotions than love conveyed through objects associated with marital abuse. Middle-class abusive men frequently removed wives' household keys, thereby preventing

77 BIHR, Cons.CP 1846/1 Mary Stephenson Ellerby, Newbiggin Hall, Egton, v. William Ellerby, West Barnby, parish of Lyth, yeoman. 1846 Cons. CP 1847/4; also Cons. CP 1847/4 Mary Bentley, v. Joseph Bentley. 78 Cons. CP 1847/4 Mary Bentley, v. Joseph Bentley. 
them performing their expected and legitimate household management duties.79 Catherine Warburton complained that her husband crept into her chamber in the morning while she was in bed and took from under her pillow 'her pockets in which she kept the keys of her linen, plate, money and other articles' that were her own property by virtue of the marriage settlement. She says she struggled to prevent him, and shrieked for help which did not come because Robert had discharged the servants that day. 80 As Foyster observes, this was a common act in cruelty cases because 'household keys were significant indicators of authority, since whoever held them governed access to both household spaces and resources'.81 Men removed the one object that gave a wife access to critically important chests and rooms within which were cash, food, clothing, linen, papers and marital property. Their loss was physical and emotional as well as symbolic; household keys were part of female clothing, tied at women's waists in pockets and baskets, and far more than women's means of access to household property. In literature, for instance, household keys represented normality and security. In David Copperfield, the 'little housekeeper' is described as having 'a little basket-trifle hanging at her side, with keys in it'. 82 In Bleak House Esther Summerson said, 'I was passing through the passages on my return with my basket of keys on my arm when Mr. Jarndyce called.' Throughout she refers to the comfort of the keys associated with their weight and jingling. Carried on the body such baskets of keys were intimate reminders of a woman's status in household and family. Removing them indicated the loss of domestic security, and a destabilised life. Women who complained about this to the

79 For wives role as household managers, see Bailey, Unquiet Lives, chapter 4.

80 Cons.CP 1800/3 Warburton c Warburton, 1799.

81 Foyster, Marital Violence, p. 53, for further examples and their ubiquity see Bailey, Unquiet Lives, p. 77.

82 Charles Dickens, Bleak House, London, 1853, pp. 66, 294; idem, David Copperfield, New Yor, 1899, pp. 266-7. 
courts revealed feelings akin to loss in addition to resentment and humiliation.

\section{The Cultural Power of the Spaces and Stuff of Marital Violence}

The spaces and objects associated with marital violence also had enormous power as evocative objects, or things to think with in text and image. One of the earliest examples was the stick, an object used to debate the distinction between correction and cruelty. In 1782 Sir Francis Buller, a judge of the Court of King's Bench, allegedly re-stated the 'rule of thumb' that a husband could beat his wife with a stick no thicker than his thumb. Ostensibly the rule reinforced men's legitimate right to correct their wives using physical force. Although the legal historian, Maeve Doggett, was unable to trace 'Judge Thumb's' statement in legislation or legal comment, people's familiarity with the concept certainly indicates that it was part of 'folklaw'.83 Indeed, its quasilegitimate status lasted for a century; although when the 'rule' was invoked in a Court of Appeal divorce case heard by the Irish Divorce Court in 1891, the Master of the Rolls laughed and rejected it.84 Their form was updated with the arrival of new materials. In an article responding to MP Lewis Dillwyn's 1856 bill to amend the Aggravated Assault Act (1835) to permit the flogging of men who beat wives or children, the author of 'Wife-Beating' depicted domestic abuse as 'a woman or child flogged into ribbons by a gutta-percha whip, wielded by a husband or father'.85 Gutta-percha, natural latex, was a rediscovered material, introduced to England in the 1840s, and used in domestic furniture, and jewellery. Here, however, the gutta-percha whip was perceived to be a vessel for pain and fear.

83 Maeve E. Doggett, Marriage, Wife-beating, and the Law in Victorian England. University of South Carolina Press, 1993, passim; Foyster, Marital Violence, p. 12; H. A. Kelly, 'Rule of thumb and the folklaw of the husband's stick', Journal of Legal Education 44, 3 (1994), 341-65. 84 Urquhart, 'Irish Divorce and Domestic Violence', 827. 
The culturally recognised object in the form of the stick conveys how material culture opened up to discussion the issue of wife-beating. Indeed, one could describe the stick in this context as an emotional object that made print culture's message about wife-beating more powerful and liable to capture public imagination. James Gillray's cartoon titled 'patent sticks for family correction: warranted lawful' (figure 1) is an excellent example. The bundle of sticks ending in thumbs, sold by 'Judge Thumb', swiftly conveys the issues to the viewer, even without the speech bubbles which emphasise the shock of the object: the wife cries 'murder' as her husband hits her with his stick and he responds: 'it's Law you Bitch: it's not bigger than my thumb'. Here too are the nascent stirrings of the increasing tendency to identify middle- and upper-class men with emotional and mental abuse of their wives and working-class men with physical violence. Elizabeth Foyster argues that this was due to a new sense of marital violence as a social wrong; higher-ranking people could thus differentiate themselves from the lower ranks by explaining that the latter were more prone to violence since they had little regard for social niceties. 86

In conjunction, the material stuff around which marital violence was enacted was increasingly invoked to disseminate, reinforce, and fix the class-stereotype of wife-beating in the public imagination. In his 1856 publication 'Outrages on Women,' also responding to Dillwyn's 1856 flogging bill, J. W. Kaye described the poor man's beaten wife's screams echoing in 'the close alley or teeming courtyard in which he dwelt,' and piercing the 'thin, dilapidated partition-

85 'Wife-Beating', Saturday Review of Politics, Literature, Science and Art, 16 May 1857, 3, 81, p. 447.

86 Foyster, Marital Violence, p. 72. By 1850 The Times referred to London labourers who beat their wives for little reason and received several letters in response which deployed a rhetoric of brutal working men, cited in Hammerton, Cruelty and Companionship, p. 27. 
walls' of the multi-household house.87 In his attempt to be sympathetic and understand workingclass men's resort to violence, Kaye focused on the strains within poor people's marriages caused by a dirty, disorganised home, the fault of the poorly educated, if well-meaning, young wife's household inadequacies. Such 'domestic misery', he observed, 'keeps the man in a continual state of anger and impatience'.88 Responding to the Divorce and Matrimonial Causes Bill, a writer in Tait's Edinburgh Magazine, in 1857, described a typical case of marital violence similarly. Here the hard-working wife of an ill-tempered, idle husband 'tried for the sake of peace to make his home as comfortable as her scanty means would allow; as her reward, she received curses, oaths and blows'.89

For these writers, the causes of wife-abuse were frequently cast through class-specific domestic objects. Kaye characterised working-class men's violence against wives, for instance, as 'the blows of pokers or hammers' in 1856.90 This was so widespread that Lisa Surridge describes the poker as the 'stereotypical instrument of working-class domestic abuse' in Victorian fiction.91 Kaye positioned middle-class men's violence through their well-appointed homes, their tempers flaring over a bell not answered, a dinner not satisfactorily cooked, slippers not brought, a book or papers disarranged'.92 John Leech's 'A Fine Disposition', 1848, used the destruction of numerous luxury household objects to attack the middle-class abusive husband's character and masculinity (figure 2). This 'Affectionate Husband,' sullenly announces: 'Come Poly, if I am a little irritable, it's over in a minute.' Depicted standing over his sitting wife, her face obscured by her fashionable ringlets, he is no respectably manly husband. The broken detritus of their once

\footnotetext{
87 W J Kaye, 'Outrages on Women', North British Review, 25, 1856, p. 236.

88 Ibid, pp. 247-48, 250.

89 'Divorce and Matrominial Causes Bill', Tait's Edinburgh Magazine, July 1857, p. 412.

90 Kaye, Outrages on Women, p. 235.

91 Surridge, Bleak Houses, pp. 7, 37.
} 
comfortable home: crockery, clock, furniture, mirror, paintings, and musical instrument, displays his petulant and contemptible act. The structure of the household and the state of the domestic objects within it were thus conceived as agents in violence. Kaye contrasted the visibility of working-class wife-beating with the invisibility of middle-class abuse, since the better-off home 'is screened and guarded by closed doors and obscuring curtains; and from the penetralia of such houses no voice can come without the consent of aides and abettors'.93

Following the passage of the Matrimonial Causes Act in 1857 these material tropes were used to question the new categories of divorce and definitions of cruelty. This was not always in women's defence. 'Divorce a Vinculo or The Terrors of Sir Cresswell Creswell', in Once A Week, 1860, was a comic tale that attacked the new divorce courts. In this serialised fictional divorce the young, exquisitely beautiful plaintiff, Mrs Barber, manipulated male court personnel and court spectators in order to exaggerate her allegations and succeed in her bid for divorce. This misogynistic tale deploys the objects and spaces of marital violence satirically to reinforce its claim that the definition of cruelty was too wide and could be exploited by wives. A pair of illustrations, for instance, contrasts the petitioner's with the defendant's account of the alleged act of cruelty. In the former, the symbols of marital cruelty were deployed, with a table and chair upended, tableware smashed on the floor, and pictures knocked askew and falling sideways; the defendant's case was illustrated by an orderly dining room.94 Contrasting domestic implements are then used to ridicule Mrs Barber's allegation that her husband tried to hit her in the face, leaving her with a heavily bruised arm when she defensively deflected the blow, with the lawyers quarrelling over whether the weapon was a bootjack or toothbrush.

92 Ibid, p. 237.

93 Kaye, 'Outrages on Women', p. 236.

94 Once A Week, 3 March 1860, 208, 209, 
The supposed vulnerability of men to unjust accusations of violence against wives is also illustrated through domestic objects. Mrs Barber next recounted that in the evening she was sitting with her injured arm in a sling, crying and, according to the sarcastic narrator, 'singing a beautiful passage in one of Watt's hymns, recommending resignation to wives in all the trials of domestic life, with the cheerful assurance that a day would come when ferocious husbands would meet with their deserts'. Hearing her 'pathetic wailing' as he returned late from his Club, Mr Barber 'was very near renewing the attack upon her.' Storming into the room, 'doing his hair with two large hair-brushes, he shouted at her "to shut up that row"'.95 Accompanying the story is an illustration of Mrs Barber sitting up in the bed with her raging husband standing alongside brandishing two hairbrushes. Its ironic title, 'Savitia - "shut up that row,"' implies that simply shouting at your wife was now deemed abuse. By taking the materiality of marital violence and ridiculing it, the story questioned wives' credibility and victimhood when given licence to end a dissatisfactory union.

If material culture was an actant in wife-beating, then for these authors it could also be an agent for good. Kaye saw the potential of household space and objects in ameliorating as well as causing violence: 'In however humble a degree, the decorative arts exercise their influence in the poor man's home it is an influence for good, which will not long suffer him to be a wife-beater and a brute'.96 For him, certain objects were vessels for positive feelings. Thus, he disputed advice that working-class men should refrain from spending their earnings on tobacco, because the 'poor man's pipe' was a 'Sunbeam' in their lives:

We write now with especial reference to the treatment of women; and we are convinced

https://archive.org/stream/onceaweek02dallgoog\#page/n215/mode/1up

95 Once A Week, 31 March 1860, p. 301. Illustration pl. 302.

96 Kaye, Outrages on Women, p. 255. 
that the pipe has a very sedative and tranquilizing effect. Much angry and bitter feeling we are convinced, is puffed out and dissipated with the fumes of the tobacco. On the whole the pipe is not an offence, but a protection to women.97

Unsurprisingly, the public did not take up the proposition that a pipe was an agent of marital bliss.

\section{Conclusion}

It is important for historians of family relationships to pursue Bound-Alberti's insightful analysis that the physical structure, spaces, and artefacts of dwellings played a constitutive part in marital behaviour. This is not to remove any personal responsibility for their actions from husbands who beat their wives. However, it helps us understand how the material world shaped men's violence, offering the most graphic evidence that spaces and objects are not merely symbolic, but agents too. Domestic spaces were imbued with tensions arising from spouses' un-demarcated and uncertain spheres of influence and authority. We still need to know how this changed over time and place, and the extent to which this repositioned domestic violence hotspots. Like spaces, objects also marked out individuals, relationships, and emotions and thus provoked actions as well as thoughts. As symbols they helped construct discourses about class, violence, and gender. As things they catalysed violent men's emotions and acts. Men wielded artefacts as weapons and destroyed those linked to their wives' pursuits and occupations because these objects had emotional power as well as a physical presence. For the wife confined, hiding from violence, or struck by a domestic object the very stuff of her material life acted alongside her husband in oppressing her.

97 Kaye, Outrages on Women, p. 253. 
9363 words $(11,291$ with footnotes $)$

Acknowledgements

The author wishes to thank Oxford Brookes University for support in carrying our research underpinning this article. She is also grateful to Katie Barclay and Lorna Campbell for their discussion of aspects of this study. Finally, she is indebted to Michael Brown for his interest in this work and his patient readings of its several iterations. 